\title{
The Skeptic's Guide to the Genealogy
}

ABSTRACT:This paper seeks to evaluate Nietzsche's positive ethical vision through a focus on the plausibility of his moral-historical account as it appears in On the Genealogy of Morals. It is then argued that Nietzsche's account of the "slave revolt in morality" contains shortcomings that necessitate further inquiry into Nietzsche's consequent ethical vision. Furthermore, the paper goes on to demonstrate that if a proper historical context for the "slave revolt in morality" cannot be identified, or if it cannot be shown that Nietzsche's ethical vision can stand without such a context, then a neo-Nietzschean ethic must be set aside.

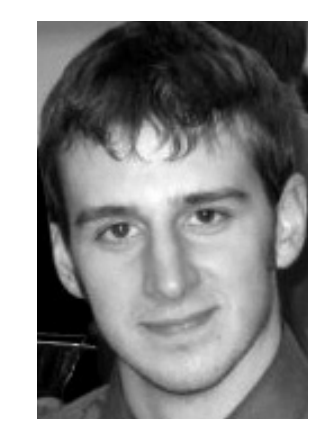

Benjamin Holvey is second-year student of philosophy and mathematics at Case Western Reserve University in Cleveland, Ohio. His interests include epistemology, logic - especially ho logos (John 1:1) - and Christian theology. He hopes to further study the intercourse between natural and formal languages and computer science. Ben entertains divine command theory, reformed epistemology, and ontological dualism. When he is not writing papers or solving math problems, he can be found with suitemates or InterVarsity friends. He is a distant relation of the pioneer and nurseryman John Chapman, better known as Johnny Appleseed.

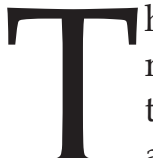
there exists within his body of work man-as-he-really-is. Pursut of the fulfill of of human nature as Nietzsche sees it will hereafter be referred to as Nietzsche's positive ethical vision. The general effort approached herein is an evaluation of this ethical vision. The specific problem which attaches to the general effort is the plausibility of his moralMoral account in On The Genegy of

Morals. Insofar as the latter is seen to effect
the former, a revaluation of Nietzsche's positive ethic is suggested. Specifically, shortcomings in Nietzsche's account of "slave revolt in morality" motivate an inquiry into the ethic which, in part, follows from it. ${ }^{1}$ I propose that any assent to a neoNietzschean ethic must be set aside until an ppropriate historical context can be found or it can be convincingly shown that there is no necessary connection between his ethic and any putative historical account which justifies it. Those views considered herein are largely original, with the occasional help of Nickolas Pappas' The Nietzsche Disappointment, to which I am indebted. 


\section{Nietzsche's Positive Ethical Vision}

In the absence of a proper treatise from Friedrich Nietzsche on his positive ethics, any systematic account of which - hampered by his oft indirect and polemical style - may proceed only from a patient analysis of "(1) proceed only from a patient analysis of "(1) what Nietzsche values, (2) what his criteria
of evaluation are, and (3) what evaluative of evaluation are, and (3) what evaluative
structure, if any, is exhibited by the answers structure, if any, is exhibited by the answers
to (1) and (2)."2 Our expectations, then, are tempered by the difficulty of Nietzschean exegesis and the speculative nature of the effort. Indeed, Leiter warns, "We go wrong at the start...if we expect Nietzsche to produce a normative theory of any familiar kind." ${ }^{3}$ Since reams have been written in pursuit of such an account and its utility here pursuit of such an account and its utility here is merely prefatory, I submit to scholarly
analysis. After all, Pappas advises that Nietzsche will yield his secrets more readily to a "sly reconnoitering" than a full-on "frontal assault." ${ }^{4}$ For Ernst Behler, whether Nietzsche's thought can be systematized is the "central question that perhaps every interpretation of Nietzsche must raise; namely, whether the philosopher's aphoristic and fragmentary text, which apparently rejects final principles and systematic
coherence, nevertheless can be read in the coherence, nevertheless can be read in the style of traditional metaphysics." ${ }^{5}$ Finding Leiter's three analytic criteria pursuant to

2. Brian Leiter, "Nietzsche's Moral and Political Philosphy," Stanford Encyclopedia of Philosophy, July 27, 2007, Stanford University Metaphysics Research Lab, http://plato.stanford.edu/entries/nietzsche-moral-political/\#2 (accessed May 3, 2008)

3. Leiter.

4. Nickolas Pappas, The Nietzsche Disappointment (Lanham, MD: Rowman \& Littlefield, 2005), xiii.

5. Ernst $B$

6. Leiter.
7. Ecce Homo I2
8. Leiter. this end, we proceed with caution.

Several prescriptive themes are discovered

the application of said criteria to others only instrumentally." 6 Second, we find that the "wellhis delight cease where the neasure of whe is good for him is transgressed." Third, whet "to revere and respect ond (to revere and respect oneself as might a god" - is arguably the highes ietzchean virtue. ${ }^{8}$ These are core tenets of extent of that which, albeit meager and rather mbiguous, may be concluded positively.

Ultimately, we find that we must resor to that which is critical in Nietzsche's moral philosophy - of which there is, by contrast no paucity - to fill out our understanding of his positive ethical vision. It is not a question of how Nietzsche would have us conduct ourselves, for this kind of question commonly has in view some code of conduct - a set of moral imperatives which directs human behavior. This is exactly the kind of morality that Nietzsche abhors. The question to ask Nietzsche is, "What kind of lifestyle worst conforms to human nature?" And, of to the character of the questioner, whether igher or lower in Nietzsche's estimation, Nietzsche's writings. First, we find that "higher types are solitary and deal with course, the answer differentiates with respect with exclusive preference given to his higher type. It suffices to say that I should think the vast majority of readers would take issue with this kind of morality or lack thereof (I am not sure how to tell between the two in this case), if not in principle, then most assuredly in practice. Moreover, there is a strong case to be made that a world full of Nietzscheans would be a most dysfunctional world. But this kind of visceral reaction is entirely beside the point. If we take issue with Nietzsche's positive ethical vision, it must be for a more substantive reason. Thus is the argument which follows.

\section{Nietzsche's Moral Account:}

The Slave Revolt in Morality

A précis of Nietzsche's argument is in order: Dissatisfied with the myopic attempts of "English" psychologists (e.g. Paul Rée), with their utilitarian bias, to explain the origin of morality as the unegoistic action forgotten, Nietzsche endeavors to explain the "good" in terms - literally speaking - of those whom themselves were "good" (i.e. the noble and the powerful), rather than those to whom goodness was first shown. ${ }^{9}$ Nietzsche's philologic inclination is made evident as he elaborates on this thesis. Employing linguistic analysis to support it, he remarks that the word for "good," in many languages, shares a root with the words "powerful," "rich," and "master". By contrast, he notes the association between the German word "bad," and the words, "plain" and "simple."10 These linguistic observations motivate the hypothetical framework for understanding the origin of orality which follows.

In what seems the central idea of Nietzsche's Genealogy, he points to the interaction between what he labels elsewhere "master morality" and "slave morality" and the proliferation of the latter as responsible for the JudeoChristian ethic which prevails in modernity. Master morality belonged to the masters powerful noble and warrior archetypes - who understood and defined themselves as "good, true to its etymological past. Their attributes of wealth, power, health, and happiness were "good" by association. The master, moreover, concerned himself with little else than the interests of self. Thus, his understanding of the "bad" developed only as an afterthought, enhancing self-perception by the contrast the master saw between himself and the plebeian "slaves" and ascetics, who were generally poor and weak and often sick. At variance with the masters and their robust attributes, the impotence of the slaves and in turn, the slaves the of the slaves and, "ban." mbodied the "bad." his understanding of "good" and "bad" constitutes master morality."

In the face of opposition and oppression the slaves began to resent the warrior caste. et powerless, the slaves could not seek revenge outwardly; rather, this resentmen became a creative force, turning inward to invent an imaginary revenge - the slave morality. Negative and reactive, the slave morality condemned the master and 
promises of blessing and eternal bliss for the meek to vindicate their temporal suffering and inferiority. Diametrically, the "good" for the slaves came as an afterthought, necessarily emphasizing kindness, humility, patience and other virtues that stood in contrast to most to , consumed the slaves, they schemed together against the masters, becoming cleverer and craftier than the unsuspecting nobles. This conspiracy ultimately lead to the "slave revolt in morality," the forceful overthrow of the masters and the universal imposition of the slave morality. Thus, the perverse moral revaluation employed thereafter disoriented "good" of the masters with the "evil" of the slaves. ${ }^{12}$

\section{Nietzsche's Historical Account: the Judeo-} Roman Context

The questions must then be asked: Withi what historical context is Nietzsche's genealogy to be understood? How is it properly and accurately manifest? Colloquially, we could ask just how does this account map onto history? Hitherto, I have, for the sake of concision Hitherto, I have, for the sake of concision,
been compelled to summarize Nietzsche's arguments. Hereafter, I cannot deny the reader access to Nietzsche proper. Listen to Nietzsche himself, from the first essay of the Genealogy, on the dawn of the slave revolt:

All that has been done on earth against "the noble" "t rulers," fades into nothing compared with

what the Jews have done against them; the Jews... were ultimately satisfied with nothing less than a radical revaluation of their enemies' values... It was the Jews, who, with awe-inspiring consistency, dared to invert the aristocratic value-equation (good = noble good = noble pow) God) and to hang on to this inversion with their teeth... saying "the wretched alone are the good; the poor, impotent, lowly alone are the good; the suffering, deprived, sick, ugly alone are pious, alone are blessed by God, blessedness is for them alone - and you the powerful and noble, are on the contrary the evil, the cruel, the lustful, the insatiable, the godless to all eternity; and you shall be the godless to all etenity; and you shall be in all eternity the unblessed, accursed, and damned!" - that with the Jews there begins the slave revolt in morality... ${ }^{13}$

How did this happen? Nietzsche elaborates:

This Jesus of Nazareth, the incarnate gospel of love, this "Redeemer" who brought blessedness and victory to the poor, the sick, and the sinners - was he not this seduction in its most uncanny and irresistible form... Was it not part of the secret black art of truly grand politics of revenge, of a farseeing, subterranean, slowly advancing, and premeditated revenge, that Israel must itself deny the real instrument of its revenge before all the world as a mortal enemy and nail it to the cross, so that... all the opponents of Is opponents of Israel, could unhesitatingly
swallow just this bait?
There are three essential observations of Josephus' Antiquities of the Jews 18:63 (ca. A.D. the Jewish "slave revolt in morality." First, 93) seems to preclude the possibility of a Jewish though not explicitly identified in either of conspiracy: "And the tribe of the Christians, these passages, one may reasonably infer so named from [Christ], are not extinct at this that the master caste is that of the Roman day." ${ }^{17}$ If Jesus was a covert agent of revolt for occupation of Judea, which had been the Jews, a feigned enemy, why was there still conquered by the Roman general Pompey in a distinct following of Christians 60 years after 63 B.C. ${ }^{15}$ Nietzsche clarifies this point later the crucifixion -60 years after Rome swallowed in the First Essay, pitting "Judea against the "bait?"

Rome." ${ }^{16}$ Second, Nietzsche affirms that the Second, it is exceedingly clear from the slave revolt begins with the Jews through Gospel account that Jesus' "new ideals" were Jesus of Nazareth. Third, the Jews succeed in not new at all. Rather, the moral instruction of the dissemination of a "radical revaluation of Christ was, by his own acknowledgement in their enemies' values."

The Plausibility of Nietzsche's MoralHistorical Account

the Gospel of Matthew, not his own, but that of another. "Do not think that I have come to abolish the Law or the Prophets; I have not abolish the Luw nor La" Law" and "the Prophets" are portions of the

The Judeo-Roman context for the slave Hebrew Tanakh (i.e. Hebrew Bible), which even revolt sounds plausible prima facie. However, the most liberal scholar would admit could scrupulous attention to the Gospel account, not have been written any later than the 2nd upon which Nietzsche's contextualization century B.C. - that is, unequivocally, before rests, and germane histories of this period the Roman occupation of Judea even began yields discord with the aforementioned third hardly "new." Further, comparison between the this discord with three conflicting observations out the truth from the Gospel and other records.

First, there is a strong case to be made First, there is a strong case to be made and Sadducees) which was the greatest of the
from the Acts of the Apostles, immediately commandments, Jesus responded famously, succeeding the four gospels in the New "Love the Lord your God with all your hear, Acts records, at length, the martyrdom of the This is the first and greatest commandment. Early Church at the hands of militant Jews. And the second is like it: 'Love your neighbor Moreover, an excerpt concerning Jesus from as yourself.'"19 The firstcommandment is found

15. S.B. Luce, "Professor Carter's Lowell Lectures on the Religious Life of the Romans," The Classical Journal 7, no. 2

(1911), http://www.jstor.org/stable/3287190 (accessed February 28, 2009).
(1)

16. Nietzsche, 52 .

17. Flavius Josephus, Antiquities of the Jews, quoted in Pappas, 134

18. Mt. 5:17 (New American Standard Bible). 
verbatim in Deuteronomy 6:5 and the second in Leviticus 19:18, both books of the Torah which antedate Christ by hundreds of years. Even the Christian virtue of humility in the Beatitudes, which Nietzsche alludes to, is commended in Psalm 37:11: "But the humble will inherit the land and will delight themselves in abundant prosperity." ${ }^{20}$ Moreover, the putative ethic of the twelve tribes of Israel - to which Nietzsche
apparently subscribes - is one of ingroup loyalty apparently subscribes - is one of ingroup loyalty and outgroup hostility. Whereas, Moses records the following command of God in Leviticus your land, you shall not do him wrong... The stranger who resides with you shall be to you as the native among you..." ${ }^{21}$ With regard to "evil," Jesus says, in Mark's Gospel, "[O]ut of men's hearts come evil thoughts, sexual immorality, hearts come evil thoughts, sexual immorality, theft, murder, adultery, greed, malice, deceit,
lewdness, envy, slander, arrogance and folly." 22 This is supposedly the thrust of the "slave morality," yet it is a reiteration of the preexisting value system of the Levitical Covenant.

Third, any Roman acceptance of the gospel was largely irrespective of the Jews; scrutiny of Roman history reveals the untenability of any other conclusion. As Pappas points out:

There is Suetonius (in Life of Claudius) in the second century mentioning 'Chrestus' who stirred up the Jews... : "

he means 'Christos' he is lumping Jews and Christians together. A generation late
Galen occasionally criticizes Christianity, likewise speaking without differentiation of the 'followers of Moses and Christ'... The purported enmity between the religions could hardly be stirring Romans who did not even notice it."2

After Galen and until the signing of the Edict of Milan by Constantine I, Roman sentiments toward Christianity only become more hostile. ${ }^{24}$

In holding the Genealogy accountable for solidarity with history, we must not neglect its plausibility in a less literal sense - we might engage it with a symbolical hermeneutic. However, we find immediately that Nietzsche himself will not let us do 列 throughout the book areconsistently historical complete with etymological support. Why else would he praise Napoleon as "the last signpost" to the master race? ${ }^{25}$ However tempting it may be to engage the Genealogy symbolically, it is clear that Nietzsche purports to deliver the genealogy of morality.

Even if we could take Nietzsche less than literally, where are the masters we now resent? How does the ass perversion, perpetuate in the face of hum perure and ineth The gap be twe of human nature and instinct? The gap between the slave revolt and modernity is left unexplored. We may well charge Nietzsche as he charged the English" psychologists concerning their theory of the unegoistic action forgotten - for deficit of explication..$^{26}$ Other questions abound. Could the weaker caste really overcome the stronger? As Pappas remarks, "How does weakness
triumph and still deserve the name?" 27 Are we really to "wed to bad conscience the unnatural inclinations," i.e., to turn the self-effacing faculty of the bad conscience against the slave sickness, as Nietzsche suggests? ${ }^{28}$ These are speculative and compelling questions which deserve greater attention than the scope and intent of this effort allow.

\section{Objections Addressed}

I now pause to address several foreseeable objections which may be made to either the objections whic premise of this effort or the arguments therein. The reader's initial reaction to arguments against the satiety of the Judeo-Roman context
may well be that there are other historical may well be that there are other historical
contexts to consider. This is true; I would only submit that Nietzsche gives none which is not contingent upon the Jewish revolt. Ignoring more speculative concerns about the genealogy and as a matter of objective history, the slave revolt is, without context, left "explicable, merely not yct explicated." 29 A collary objection merely notyetexplicated. Acorollary objection revolt neither needs nor desires a definitive revolt neither needs nor desires a definitive context, that its consummation is covert and gradual rather than so forcefully abrupt, and, consequently, that, given Nietzsche's style, the Jewish conspiracy is appropriately metaphorical or symbolic. But it is certain that Nietzsche does not contextualize the slave evolt in this manner. Moreover, it is in this case which Nietzsche's causal explanations, already trained, defy near-insurmountable odds. A Pappas writes, "The cause cannot work, or stands in need of a cause itself." ${ }^{\prime 30}$ Specifically, a protracted understanding of the revolt denies it the paradigm-shifting dynamic, which is perhaps its single virtue to Nietzsche (it lends humanity greater depth and makes it more "interesting"). From the and makes it more the slave reverom the sociodynamic lexicon, the slave revolt never reaches "critical mass," too anemic and unequipped for ascendance to power. Roughly speaking, the revolt is never galvanized; there is no nexus between ssentiment and revolution.

It might also be said that I take the gospel It might also be said that I the the gospel liter ly, ignoring the posibility by the Early Church to con Jewish conspiracy. However, I wager no more on the gospel account than Nietzsche himself think that is evident. That the evangelists could have written whatever they liked concerning the life and instruction of Jesus is almost a truism. Notwithstanding, that instruction as recorded in the gospels derives from a Mosaic Law which predates any possib Roman slave revalt. Of this tension betweoassent to the his. Or this terty dental of its investedicity of the Gospel and derial of its invested theology, Pappas notes, "[Nietzsche] needs the Gospel of John to exis so that the astonishment of the Genealogy may shine forth. But he also needs it not too exist so that his thoughts can have the spontaneity and independence he prizes so highly." ${ }^{\prime 31}$ 


\section{The Skeptic's Guide to the Genealogy}

There is one fourth and final objection which ethic, informally, things as they should be?" deserves consideration especially as a matter of In his critique of modern morality, Nietzsche thesis defense. That is, it challenges the premise expresses particular disdain for its infringemen of this effort and calls for the natural conclusion on his "higher men," a patrilineage which finds of the argument. Namely, the evaluation of its distinctive source in the genealogy. ${ }^{33}$ If the Nietzsche's positive ethic does not involve his genealogy is defunct, is it conceivable that the moral-historical genealogy. On the contrary, slave mentality is less a subversion of human the evidence against this objection is twofold. nature than Nietzsche would have us think $\begin{array}{ll}\text { the evidence against this objection is twofold. } & \text { nature than Nietzsche would have us think } \\ \text { First, Nietzsche denies this himself: } & \text { and more a consequence of it? If this takes the }\end{array}$ argument too far, there remains at least worthy

I end up with three question marks; that consideration in the possibility that the higher seems plain. 'What are you really doing, mentality was never overcome by the lower erecting an ideal or knocking one down?' but that it fell extinct autonomously from the I may perhaps be asked. But have you human psychological genome. This, in turn ever asked yourselves sufficiently how begs the question, "Can it even be revived?" much the erection of every ideal on earth It is beyond the scope of this effort to consider mas cost? How much reality has had to be in detil what has cos? How misunder lies have had to be sanctified, how many however, as a consequence of the evidence consciences disturbed, how much 'God' detailed herein, that any assent to a neosacrificed every time? If a temple is to be Nietzschean ethic must be set aside until a erected a temple must be destroyed: that historical context can be found or it can be is the law - let anyone who can show me a convincingly shown that there is no necessary case in which this is not fulfilled. ${ }^{32}$

connection between his anti-morality and any putative historical account which justifies it.

Here, it seems, Nietzsche emphasizes What is Nietzsche without his genealogy? that the destruction of an ideal is necessarily Certainly, the Genealogy remains an astonishing antecedent to the "erection" of another, as if to and monumental development in the history say that by sabotaging the herd mentality - by of moral philosophy. I have endeavored not revealing the lies and slander it sanctified and to dismiss it, but, by challenging it, to add the perversion it promulgated - he has cleared some small contribution to the field and the way for his positive ethical vision. Second, perhaps encourage further investigation of there is substance in the question, "how does Nietzsche's work.

Nietzsche's genealogy inform his positive

32. On Morals of Genealogy II 24.

33. Friedrich Nietzsche, Beyond Good and Evil, trans. Walter Kaufmann (New York: Vintage, 1966).

Acknowledgement: I am indebted to Dr. Jeffrey Stephenson, Visiting Assistant Professor of Philosophy at Case Western Reserve University. student Ry Pierce, who reviewed the penthima deft and posed wothy objection. 